\title{
THE TAX REFORM ACT OF 1969: CONSEQUENCES FOR PRIVATE FOUNDATIONS*
}

\author{
K. Martin WORThY $\dagger$
}

INTRODUCTION

Most provisions of the Tax Reform Act of 1969 which affect private foundations now have been in effect for seven years. ${ }^{1}$ These provisions frequently have been described as the most far-reaching legislation affecting private philanthropy in our two hundred-year history.

Some supporters of the 1969 legislation regarded it as a means of transferring from the private to the public sector some of the social services which in the past had been supported almost entirely, or at least significantly, by private philanthropy. ${ }^{2}$ As the 1969 Act moved through the legislative process, one less than enthusiastic Senator described one of its provisions as an obvious attempt "to cut off the dog's tail an inch at a time." 3 Shortly after enactment, another contemporary commentator concluded, "[t]he bell may well have faintly tolled for the private foundation; it is now to be found only in captivity and there are strong doubts about its ability to reproduce." 4 It is perhaps now appropriate to take stock, to see whether, based on seven year's experience, these original concerns have been borne out and whether changes in some or all of the 1969 provisions are needed.

\footnotetext{
* This article is based in part on remarks made by the author at the Institute on Exempt Organizations of the Southwestern Legal Foundation in Dallas, Texas, on January 16, 1975.

$\dagger$ Hamel, Park, McCabe \& Saunders, Washington, D.C.; Chief Counsel, Internal Revenue Service, 1969-72; Chairman, Section of Taxation, American Bar Association, 1973-74.

1. Internal Revenue Code sections $170(\mathrm{~b}), 4940,4942,4943$, and 4948 , as added or amended by the Tax Reform Act of 1969, Act of December 30, 1969, Pub. L. No. 91-172, 83 Stat. 533 , were first effective for taxable years beginning after December 31, 1969. INT. REv. CodE of 1954, $\S \S 170(\mathrm{~b}), 4940,4942,4943,4948$. Internal Revenue Code sections 507, 509, 4941, 4944, 4945, 4946, and 4947, as added by the Tax Reform Act of 1969, first became effective January 1, 1970. INT. Rev. Code of 1954, $\$ 507,509,4941,4944-47$. Internal Revenue Code sections 508(a), (b), \& (c), as added by the Tax Reform Act of 1969, became effective October 9, 1969. InT. REv. Code of $1954, \S 508(a)$, (b), (c).

2. See, e.g., Norton, The Challenge for Creative Philanthropy, in Philanthropy in the Seventies 84 (1970); Creel, The Role of the Foundation in Today's Society, in N.Y.U., 9TH BIENNIAL Conference on Charitable Foundations 2-3 (1969). See also M. Fremont-Smith, Foundations and GovernmeNt 49-53 (1965). For an earlier concern about this problem, see the interesting historical account in Liles \& Blum, Detelopment of the Federal Tax Treatment of Charities, 39 LAw \& Contemp. Prob. no. 4 , at 6 (1975).

3. 115 CONG. REC. 37493 (1969) (remarks of Senator Curtis of Nebraska).

4. Taggart, The Charitable Deduction, 26 TAX L. REv. 63, 65 (1970).
} 
During the past two years, three important studies have become available as to the actual impact during these seven years of the 1969 legislation on charitable giving and private foundations in particular. The first of these is a forty-two page report of a study conducted under sponsorship of the American Bar Foundation, entitled "The Impact of the Private Foundations Provisions of the Tax Reform Act of 1969: Early Empirical Measurements," written by John R. Labovitz, a research associate at the Brookings Institution. ${ }^{5}$ The second is a Report and Recommendations to the Commission on Private Philanthropy and Public Needs on Private Philanthropic Foundations, prepared by the chairman and staff of the Council on Foundations, Incorporated, and released last year. ${ }^{6}$ Finally, there is the report by Chairman Vance Hartke of Indiana, issued October 1, 1974, on the activities, conclusions, and recommendations of the Senate Finance Committee, Subcommittee on Foundations. ${ }^{7}$ All three reports are based on extensive fact-finding: the American Bar Foundation's Labovitz study, on an examination and comparison of information returns (Form 990-A), on reports of a scientifically selected sample of 388 foundations throughout the country having assets ranging from a few thousand dollars to more than ten million dollars, on interviews with various foundation officials, and on information derived from other published sources. The Council on Foundations' report is based on a comprehensive questionnaire sent by the Council to 2,248 foundations of various kinds and sizes, including both Council members and non-members. Although there was only a 25 per cent response to the Council's questionnaire, the results appear to be quite meaningful. The Hartke Report is based largely on oral and written statements received by the Senate Subcommittee on Foundations from the Treasury Department and also on its hearings conducted October 1 and 2, 1973, May 13 and 14,1974 , and June $3,1974 .{ }^{\circ}$ In addition it relies to a lesser extent on oral and written statements received by the Subcommittee on Domestic Finance of the House Committee on Banking and Currency at hearings it held on April 5 and $6,1973,{ }^{9}$ and on statements received by the House

5. Labovitz, The Impact of the Pritate Foundations Provisions of the Tax Reform Act of 1969: Early Empirical Measurements, 3 J. Legal Studies 63 (1974) [hereinafter cited as Labovitz].

6. Council on Foundations, lnc., Report and Recommendations to the Comm'n on Private Philanthropy and Public Needs of Private Philanthropic Foundations (1975) [hereinafter cited as Council REPORT].

7. 120 Cong. Rec. 18313 (daily ed. Oct. 4, 1974) [hereinafter cited as Hartke Report]. In releasing the report, Senator Hartke noted that the "conclusions and recommendations in this statement are my own and are concurred in by the other individual members of the subcommittee to the extent indicated herein." Id.

8. Hearings on The Role of Private Foundations in Today's Society and a Review of the Impact of Charitable Pronisions of the Tax Reform Act of 1969 on the Support and Operation of Pritiate Foundations Before the Subcomm. on Foundations of the Senate Comm. on Finance, 93d Cong., 1st \& 2d Sess. (1973-74).

9. Hearings on Tax-Exempt Foundations and Charitable Trusts: Their Compliance with the Pronisions of Tax Reform Act of 1969 Before the Subcomm. on Domestic Finance of the House Comm. on Banking and Currency, 93d Cong., lst Sess. (1973). 
Ways and Means Committee at hearings it held on April 9 and 10, 1973. ${ }^{\prime \prime}$ There have, of course, been other published studies on the impact of the 1969 legislation, ${ }^{11}$ but these three appear to contain far more factual data than has heretofore been available.

I

\section{Complexity-Increased Costs of Administration}

First of all, there seems to be general agreement that the operating responsibilities imposed on private foundations of the new law and its complexities have resulted in a significant increase in administrative costs, particularly in legal and accounting services which, according to the Labovitz survey, roughly doubled between 1967 and $1970^{12}$ and, according to the Council Report, between 1968 and $1973 .{ }^{13}$ Total administrative expenses of the average foundation went up 66 per cent from 1968 to 1973, according to the Council Report. ${ }^{14}$ Although the Council Report respondents indicated that only about half of the increased administrative cost is attributable to the Tax Reform Act, ${ }^{15}$ clearly some of this additional cost of compliance undercuts a stated objective of the Tax Reform Act-to require that a greater portion of foundation assets be made available for current charitable purposes. ${ }^{16}$ None of the reports suggests any solution for the problem of increased administrative costs; indeed, the Council Report suggests that many foundations continue to be understaffed. ${ }^{17}$

10. Hearings on General Tax Reform Before the House Ways and Means Comm., 93d Cong., 1st Sess. (1973)

11. See, e.g., Labovitz, 1969 Tax Reforms Reconsidered, in The FUTURE of Foundations 101 (F. Hermann ed. 1973), a forerunner of the Labovitz study discussed here. Dressner, Learning to Live With the Tax Reform Act, in Tax Institute of America, Tax Impacts on Philanthropy 121 (1972); J. Watson, The Impact of the Tax Reform ACt of 1969 on Company foundations (1973).

12. Labovitz 78. In many instances the Labovitz figures are broken down by size of foundation: those with assets of less than $\$ 200,000$; those with assets between $\$ 200,000$ and $\$ 1,000,000$; those with assets between $\$ 1,000,000$ and $\$ 10,000,000$; and those with assets over $\$ 10,000,000$. For purposes of simplicity in presentation, the present author has relied in many instances on weighted averages of the Labovitz figures based on the number of foundations in each size group as shown in the Labovitz study. The weighted averages do not appear in the Labovitz study and often the severity or degree (or sometimes even the direction) of change for foundations of one size group is not the same as for foundations of another size group; nevertheless, the weighted averages used herein are believed to be fairly representative of general indications of impact of the 1969 Act.

13. Council Report III-6, fig. 3. Certainly the experience of the author and other lawyers is that the problems faced by private foundations are both far more numerous and far more sophisticated today than seven years ago.

14. Council. Report III-6, fig. 4.

15. Council Report III-6, III-7.

16. See the discussion of Internal Revenue Code sections 4942 and 4944 in the Finance Committee Report on the 1969 Act, S. ReP. No. 552, 9 lst Cong., lst Sess. 35, 45, 46 (1969). See also Hartke Report (discussion of the effect of increased costs on foundation recipients).

17. COUNCIL RePORT III-7, III-8. 
Something can-and should-be done about the undue complexity of the Act. First, many of the arbitrary rules, such as those in sections $170,{ }^{18} 509,{ }^{19}$

18. See, e.g. INT. REv. CODE of 1954. $\$ 170(\mathrm{~b})(1)(\mathrm{A})(\mathrm{vii}),(\mathrm{b})(1)(\mathrm{E})(\mathrm{iii})$. These provisions permit a deduction to qualify for the 50 per cent limitation instead of the usual 20 per cent limitation applicable to private foundations, in the case of:

(iii) a private foundation all of the contributions to which are pooled in a common fund and which would be described in section $509(\mathrm{a})(3)$ but for the right of any substantial contributor (hereafter in this clause called "donor") or his spouse to designate annually the recipients, from among organizations described in paragraph (1) of section 509 (a), of the income attributable to the donor's contribution to the fund and to direct (by deed or by will) the payment, to an organization described in such paragraph (1), of the corpus in the common fund attributable to the donor's contribution; but this clause shall apply only if all of the income of the common fund is required to be (and is) distributed to one or more organizations described in such paragraph (1) not later than the $15 \mathrm{th}$ day of the third month after the close of the taxable year in which the income is realized by the fund and only if all of the corpus attributable to any donor's contribution to the fund is required to be (and is) distributed to one or more of such organizations not later than one year after his death or after the death of his surviving spouse if she has the right to designate the recipients of such corpus.

Also see the half-page special limitation in INr. Rev. CoDe of 1954, $\$ 170(\mathrm{~b})(\mathrm{l})(\mathrm{D})$, permitting a deduction of up to 30 per cent-instead of 20 per cent for most gifts to some charities (including most private foundations) as provided in $\$ 170(\mathrm{~b})(1)(\mathrm{B}), 50$ per cent for most gifts to other charities (including some private foundations) as provided in $\S 170(\mathrm{~b})(1)(\mathrm{A})$, or 100 per cent as provided in some circumstances in $\$ 170(\mathrm{~b})(1)(\mathrm{C})$ - for contributions of certain capital gains property, subject to the following election:

(iii) At the election of the taxpayer (made at such time and in such manner as the Secretary or his delegate prescribed by regulations), subsection (e)(1) shall apply to all contributions of capital gain property (to which subsection $(e)(1)(B)$ does not otherwise apply) made by the taxpayer during the taxable year. If such an election is made, clauses (i) and (ii) shall not apply to contributions of capital gain property made during the taxable year, and in applying subsection (d)(I) for such taxable year with respect to contributions of capital gain property made in any prior contribution year for which an election was not made under this clause, such contributions shall be reduced as if subsection (e)(1) had applied to such contributions in the year in which made.

19. See, e.g., INT. REv. Code of $1954, \S 509(\mathrm{a})$. This provision defines a private foundation as any organization described in section $501(\mathrm{c})(3)$, other than, among other things:

(2) an organization which-

(A) normally receives more than one-third of its support in each taxable year from any combination of-

(i) gifts, grants, contributions, or membership fees, and

(ii) gross reccipts from admissions, sales of merchandise, performance of services, or furnishing of facilities, in an activity which is not unrelated trade or business (within the meaning of section 513), not including such receipts from any person, or from any bureau or similar agency of a governmental unit (as described in section $170(\mathrm{c})(1))$, in any taxable year to the extent such receipts exceed the greater of $\$ 5,000$ or 1 percent of the organization's support in such taxable year, from persons other than disqualified persons (as defined in section 4946) with respect to the organization, from governmental units described in section $170(c)(1)$, or from organizations described in section $170(b)(1)(A)$ (other than in clauses (vii) and (viii)), and

(B) normally receives not more than one-third of its support in each taxable year from gross investment income (as defined in subsection (e)).

INT. Rev. CoDe of $1954, \S 509(a)(2)$. 


\section{$642,664,,^{21}$ and $4943^{21}$ need to be eliminated. ${ }^{22}$ Second, some of the esoteric}

20. See, e.g., the definitions of "pooled income funds," "charitable remainder annuity trusts," and "charity remainder unitrusts"- the only types of trust now qualified under Internal Revenue Code section $170(\mathrm{f})(2)$ to receive deductible contributions in trust-as defined in sections 642(c)(5) and 664(d), as follows:

(5) DEFINITION OF POOLED INCOME FUND.-For purposes of paragraph (3), a pooled income fund is a trust-

(A) to which each donor transfers property, contributing an irrevocable remainder interest in such property to or for the use of an organization described in section $170(\mathrm{~b})(\mathrm{l})(\mathrm{A})$ (other than in clauses (vii) or (viii)), and retaining an income interest for life of one or more beneficiaries (living at the time of such transfer).

(B) in which the property transfer by each donor is commingled with property transferred by other donors who have made or make similar transfers,

(C) which cannot have investments in securities which are exempt from the taxes imposed by this subtitle,

(D) which includes only amounts received from transfers which meet the requirements of this paragraph,

(E) which is maintained by the organization to which the remainder interest is contributed and of which no donor or beneficiary of an income interest is a trustee, and

(F) from which each beneficiary of an income interest receives income, for each year for which he is entitled to receive the income interest referred to in subparagraph (A), determined by the rate of return earned by the trust for such year.

For purposes of determining the amount of any charitable contribution allowable by reason of a transfer of property to a pooled fund, the value of the income interest shall be determined on the basis of the highest rate of return earned by the fund for any of the 3 taxable years immediately preceding the taxable year of the fund in which the transfer is made. In the case of funds in existence less than 3 taxable years preceding the taxable year of the fund in which a transfer is made, the rate of return shall be deemed to be 6 percent per annum, except that the Secretary or his delegate may prescribe a different rate of return.

INT. Rev. Code of $1954, \S 642$ (c)(5)

(d) DEFINITIONS.-

(1) CHARITABLE REMAINDER ANNUITY TRUST.-

For purposes of this section, a charitable remainder annuity trust is a trust-

(A) from which a sum certain (which is not less than 5 percent of the initial net fair market value of all property placed in trust) is to be paid, not less often than annually, to one or more persons (at least one of which is not an organization described in section $170(\mathrm{c})$ and, in the case of individuals, only to an individual who is living at the time of the creation of the trust) for a term of years (not in excess of 20 years) or for the life or lives of such individual or individuals,

(B) from which no amount other than the payments described in subparagraph (A) may be paid to or for the use of any person other than an organization described in section $170(\mathrm{c})$, and

(C) following the termination of the payments described in subparagraph (A), the remainder interest in the trust is to be transferred to, or for the use of, an organization described in section 170 (c) or is to be retained by the trust for such a use.

(2) CHARITABLE REMAINDER UNITRUST.-For purposes of this section, a charitable remainder unitrust is a trust-

(A) from which a fixed percentage (which is not less than 5 percent) of the net fair market value of its assets, valued annually, is to be paid, not less often than annually, to one or more persons (at least one of which is not an organization described in section $170(\mathrm{c})$ and, in the case of individuals, only to an individual who is living at the time of the creation of the trust) for a term of years (not in excess of 20 years) or for the life or lives of such individual or individuals,

(B) from which no amount other than the payments described in subparagraph (A) may be paid to or for the use of any person other than an organization described in section $170(\mathrm{c})$, and

(C) following the termination of the payments described in subparagraph (A), the 
concepts, such as whether an organizaton is "operated, supervised or controlled by or in connection with" a publicly supported organization within the meaning of section 509(A)(3), and the "responsiveness" and "attentiveness" tests added as a gloss thereon by the regulations, ${ }^{23}$ need to be clarified or eliminated. ${ }^{24}$ Finally, the basic philosophy that every possible "loophole" ought to be closed, however minimal the abuse by a few clever opportunists and however burdensome compliance by the many real philanthropists, should be changed.

II

\section{Distribution Requirements}

\section{A. Minimum Rate of Return}

Turning to specific provisions applicable to private foundations, both the Labovitz study and the Council Report indicate that non-operating foundations

remainder interest in the trust is to be transferred to, or for the use of, an organization described in section $170(\mathrm{c})$ or is to be retained by the trust for such a use.

(3) EXCEPTION.- Notwithstanding the provisions of paragraphs $(2)(A)$ and (B), the trust instrument may provide that the trustee shall pay the income beneficiary for any year-

(A) the amount of the trust income, if such amount is less than the amount required to be distributed under paragraph (2)(A), and

(B) any amount of the trust income which is in excess of the amount required to be distributed under paragraph $(2)(A)$, to the extent that (by reason of subparagraph (A)) the aggregate of the amounts paid in prior years was less than the aggregate of such required amounts.

INT. Rev. CoDe of 1954, § 664(d).

21. Int. Rev. CoDe of $1954, \S 4943$. These rules-and the transitional provisions of section $101(1)(4)$ of the $1969 \mathrm{Act}$ which accompanied them-are much too complex to be set out, or even summarized here, but their frequent reference to 20 per cent holdings in some circumstances, 35 per cent in others, 50 per cent in others, 75 per cent in others, and 95 per cent in others-with the applicablity of such percentages dependent in some cases upon another 2 per cent or 15 per cent holding; to five-year, ten-year, fifteen-year, and twenty-year periods in different circumstances; and to different rules dependent upon circumstances on May 26, 1969, or January I, 1971 , are illustrative of the difficulties and the differences in result which ensue dependent upon slight differences in fact.

22. The list of sections referred to is not exhaustive, but merely illustrative of the problem.

23. Treas. Reg. $\$ 1.509(a)-4$ (1972). No section caused greater difficulties than section 509 (a) (3) in the drafting of regulations while the author was in the government. The problem of reconsidering the language, concepts, and legislative history of sections $170(\mathrm{~b})(\mathrm{l})(\mathrm{vi})$, as it was added in 1964 and the regulations promulgated thereunder, with the similar language, but varying concepts and legislative history of section $170(\mathrm{~b})(1)(\mathrm{iv})$, and section 509(a)(3) of the 1969 Act, posed an extremely difficult challenge to those charged with drafting the regulations under the 1969 Act.

24. The author was advised in a case by the ruling authorities at the Internal Revenue Service that if three publicly supported organizations depend for more than 25 per cent of their support on one foundation-more in every instance than any other single source-the Service will not consider the three public charities, in the absence of some greater dependency or control, to be sufficiently "attentive" to affairs of the foundation to meet the "attentiveness" rule of the "integral part" test set out in Treas. Reg. \$ 1.509(a)-4(i)(3)(iii)(b) (1972). It is submitted that any charity which is indifferent to such a foundation under such circumstances either ought to have its trustees and management changed or its support cut off. 
generally are confronted with very serious problems in meeting the requirement of section 4942, which became fully effective in 1975. Under such provision, such foundations must distribute for charitable purposes an amount equal to adjusted net income for the year or a specified percentage minimum return on investment assets. ${ }^{25}$ The minimum return was originally fixed by Congress at six per cent for the year 1970, subject to adjustment each year by the Treasury Department based on the same relationship to current "money rates" and "investment yields" as six per cent bore to existing "money rates" and "investment yields" in 1969. ${ }^{26}$ New foundations were required to meet the minimum return requirements immediately, but foundations in existence prior to 1969 were not required to meet the minimum return requirements at all in 1970 and 1971 and were required to meet only three-fourths of the full requirement in 1972, five-sixths in 1973, and eleven-twelfths in $1974 .^{27}$

Legislative history indicates that the six per cent minimum return was based on the assumption that foundations should be able to earn an average return of at least eight per cent on their investment, and that if the amount were fixed at six per cent they would be able to set aside two per cent each year to maintain the purchasing power of their assets, two per cent representing the approximate rate of inflation over the preceding ten years. ${ }^{28}$ The Labovitz study shows that in 1967 roughly a third of the foundations earned less than six per cent on their investments and that in 1970 over half of the foundations earned less than a six per cent return. ${ }^{29}$ Although less precise, the Council Report indicates that-despite the fact that a great many of the responding foundations changed their investment practices after enactment of the $1969 \mathrm{Act}^{3 \prime \prime}-53$ per cent still failed to attain the minimum return in $1973 .{ }^{31}$

25. Although it will not lose its status as an exempt organization for ordinary tax purposes, a non-operating foundation, in the event of failure to pay out the amount required, is subject to an initial tax of 15 per cent on the amount undistributed at the beginning of the succeeding taxable year and an additional tax of 100 per cent on the amount still undistributed within a "correction period" (normally 90 days after notice by the Commissioner). INT. REv. Code of 1954, $\$ 4942$.

26. Id. \& $4942(\mathrm{e})$.

27. Tax Reform Act of 1969, Pub. L. No. 91-172, § 101(1)(3), 83 Stat. 534.

28. See Hearings on H.R. 13270 Before the Senate Comm. on Finance, 91 st Cong., lst Sess. 6170 (1969); 115 Cong. Rec. S15956 (daily ed. Dec. 6, 1969); H.R. ReP. No. 782, 91 st Cong., lst Sess. 281 (1969). See also Commission on Foundations and Private Philanthropy, Foundations, Private Giving and Public Policy $147-49$ (1970).

29. Labovitz 88-90. In a letter to Senator Vance Harke, Assistant Secretary of the Treasury Frederic Hickman acknowledged that during the years 1970 to 1974 the "minimum pay-out requirement has exceeded average dividend yields (for the years 1969 to 1973) by 2.3 percent." Secretary Hickman noted that "a private foundation investing in low dividend securities... might make minimal charitable contributions and exist primarily as a vehicle for wealth accumulation" through retention of corporate earnings not distributed as dividends and suggested that Congress accordingly deliberately "set the minimum distribution requirement at a rate substantially above average dividend yields." Letter from Frederic Hickman to Vance Hartke, Nov. 22, 1974 .

30. Council RePort III-13, example 4.

31. Id. 
Many foundations, of course, even prior to the 1969 Act, paid out more than current income, often passing on current gifts received instead of adding them to corpus. The Labovitz study shows, however, that in 1967,56 per cent of the foundations paid out less than would then have been required "if the distribution requirement, with a $6 \%$ minimum investment return, had been in effect." 32 The record was even worse in $1970 .{ }^{33}$ The study also indicates that foundations with assets of less than two hundred thousand dollars would have had to increase their payout 4.7 per cent in order to meet the distribution requirement; those with assets between two hundred thousand dollars and one million dollars, 9.5 per cent; those with assets between one million dollars and ten million dollars, 17.1 per cent; and those with assets of ten million dollars, a whopping 57.8 per cent. ${ }^{34} \mathrm{It}$ is true that some of these foundations would have been able to meet the payout requirements by "setting aside" additional amounts for specific projects qualifying as constructive distributions under section $4542(\mathrm{~g})$, but since such amounts must be paid out in any event within five years, this would have been only a temporary solution. The fact is that these figures clearly suggest that many foundations, as a result of the 1969 legislation, must increase their payout and, in order to do so, must either significantly increase their investment return or else erode capital. It should be noted, however, that if investment policy has deliberately sought less current income in order to achieve growth in value of the investments, the required distribution may do no more than force the distribution of what would otherwise be unrealized appreciation in value, which, it may be argued, is income in the economic sense.

The Council Report indicates that 75 per cent of the foundations answering its questionnaire have, in fact, increased their payouts from 1969 to $1974 ;^{35}$ it also reports-based on information compiled from other sources-that foundation distributions rose 5.4 per cent in 1970, 8 per cent in 1971, and 7.3 per cent in $1972 .{ }^{36}$ Even so, such increases are not enough since the report also shows that the actual payout rate for non-operating foundations in 1973 averaged only 5.6 per cent ${ }^{37}$-still less than the minimum required for every foundation in $1975 .^{38}$

To meet this problem, the Council Report shows that 39 per cent of their respondents have "revised their [investment] practices since 1969" as a result of the 1969 Act, and well over half the revisions reported were intended to

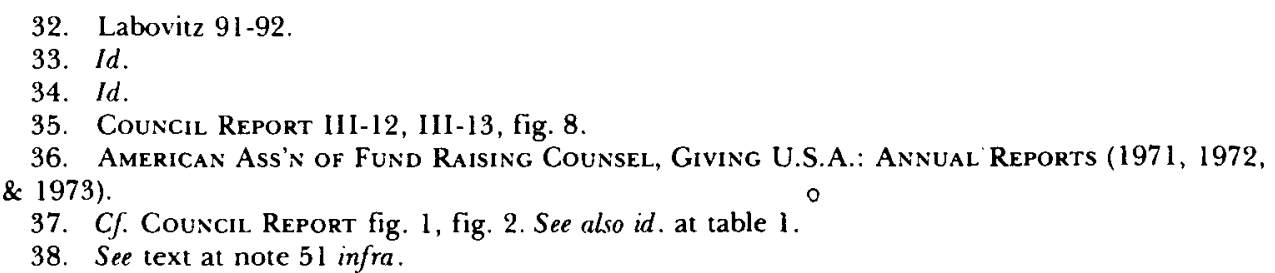


increase yields. ${ }^{39}$ Labovitz reports that many foundations have shifted to a policy of finding investments with a high enough current yield to meet the six per cent return and have abandoned emphasis on long-term performance, even though many foundations appear to differ with Congress on whether this is in the ultimate interest of the charities they benefit, believing that high fixed yield investments rarely give adequate protection against inflation. " On the other hand, critics might suggest that the foundations may have better protected themselves against inflation in the past by use of fixed income investments (which generally produce high current yields) instead of speculative growth stocks. The Council's report shows, for example, that thirty large and middle-size foundations suffered a 26 per cent decline in the value of their assets in a $8 \frac{1}{2}$ month period in $1973 .{ }^{41}$

The Council Report also indicates that foundations may have been more willing to shift investment policy had capital gains not been subject to the four per cent tax on investment income ${ }^{42}$-a subject discussed below. ${ }^{43}$

The alternative to changing investment policy to produce a high current yield-invading corpus-is, of course, abhorrent to old-fashioned businessmen and many foundation managers seeking to build their endowment at the expense of current spending. A shrinking endowment may have been just the result desired by many of those sponsoring the 1969 legislation, particularly those who think that all foundations should have a limited life. ${ }^{44}$ Old fashioned or not, it would seem apparent that if capital currently set aside to produce income for charity is dissipated over a period of time and the amount of new capital is also reduced-as evidence referred to later further indicates ${ }^{45}$ - the total contribution of private philanthropy to society will steadily diminish.

\section{B. Possible Solutions}

Several suggestions to solve the plight of the foundations have evolved. The most obvious, and the one most often mentioned, is simply to reduce the required minimum distribution. The Hartke Report concludes, however, that "While some foundations support a reduction in the applicable percentage from 6 to 5 percent... there is no evidence that the 5 percent rate is a

39. Council Report III-13, example 4.

40. Labovitz 87-88. See also Council Report III-14.

41. Council Report I1-4, quoting from Americax Ass'i of Fund Raising Counsel, Giving

U.S.A.: ANNuAl RePORT 14 (1974).

42. Council Report III-5.

43. See text at note 69 infra.

44. The Senate Finance Committee recommended, when the 1969 legislation was being considered, that private non-operating foundations be limited to a forty-year life, but this was rejected by the Senate. See 115 Cosg. Rec. S15956-963 (daily ed. Dec. 6, 1969); S. Rep. No. 552, 91 st Cong., lst Sess. 25-26 (1969).

45. See text at notes 98 \& $99 \mathrm{infra}$. 
proper one, or that it would not require an invasion of foundation corpus." "4 The report goes on to say that there is no hard "statistical data about the actual rates of return achieved by all classes of investors over long stretches of time," and that until such information is available, Congress is not prepared to act. ${ }^{47}$ The Council Report, on the other hand, contains data from four sources-one a highly respected study by the University of Chicago-which show that the average rate of return to all investors in common stocks over long periods of time, forty years or more, has averaged something under five per cent, after taking into account changes in values of the stocks themselves and the effect of inflation thereon. ${ }^{48}$ This suggests that the assumption of Congress that foundations should expect a normal rate of return of eight per cent or more and be able to distribute six per cent and have two per cent left to of fset the effect of inflation is simply unsound, particularly in light of our recent experience with double-digit inflation. ${ }^{49}$

The Hartke Report does propose that in exercising its authority to adjust the six per cent yield fixed by the statute for changes in "money rates" and "investment yields" since 1969, the Treasury has relied entirely too much on interest rates and not enough on overall investment yield."." The Treasury has already indicated that the rate will be adjusted upward this year to seven per cent.51 Both the Hartke Report and the Council Report further suggest that the rate of return should be fixed on the basis of experience over a much longer period of time than one year. ${ }^{52}$ The author further submits that, considering the volatility of the market and also the need for foundations to have some flexibility in accumulating funds when current program demands appear less important than likely later demands, foundations should be permitted a five or ten-year period in which to average out the fulfillment of the distribution requirement. It is true that an amount set aside for a specific charitable purpose may be treated as a current contribution under section $4942(\mathrm{~g})(2)$, if the Commissioner is satisfied in advance that "(A) the amount will be paid for the specific project within 5 years, and $(B)$ the project is one which can be better

46. Hartke Report 18317.

47. Id.

48. Council RePort III-15.

49. Ten and wo-tenths per cent in 1974, according to the Wall Street Journal, Jan. 17, 1975, at 2 , col. 2 .

50. Harke Report 18317. In a letter to Senator Vance Hartke, Assistant Secretary of the Treasury Frederic Hickman defended the Treasury practice of relying in 1973 and 1974 solely on "change in yield on 5-year Treasury securities," on the grounds that they are more representative of "enduring investments in investment yields" than dividends. He also contended that dividends are not a true measure of investment return because they ignore increases in value resulting from retained earnings, see note 29 supra, but showed that in any event the payout requirement relative to 1969 would have been higher if dividends had been taken into account. Letter from Frederic Hickman to Vance Hartke, Nov. 22, 1974.

51. $I d$

52. Hartke Report 18317; Couscil. RePORT V1-9. 
accomplished by such set aside than by immediate payment of funds." 53 This does give some flexibility, but it does not furnish any solution at all to the situation where there simply is nothing in being or yet advanced beyond the planning stage which is likely to be as meritorious as something which may come into being or develop beyond the planning stage within the next several years. The present law compels a distribution (or set-aside) for which the foundation may have little enthusiasm at the expense of more worthwhile projects which may come later. The 1969 Act contains a carryover provision under which foundations making distributions in excess of the minimum requirements may apply such excess against distribution requirements in the future; ${ }^{54}$ there should be a carryback provision over a limited period of time as well.

\section{III}

\section{Other Investment Problems}

\section{A. Controlled Businesses}

None of the three reports contains any information with respect to the impact of the prohibition on investments which jeopardize exempt purposes contained in section $4944 .^{55}$ There is evidence, however, in both the Labovitz study and the Council Report that the prohibition in section 4943 on the ownership of more than 20 per cent of the stock of a single business will, in due course, have a substantial impact on many foundations. ${ }^{56}$ In most instances foundations have ten years to dispose of their excess holdings ${ }^{57}$ and in some instances an even longer period, ${ }^{58}$ so that for those who wish to delay, this section has had no immediate effect other than on planning for the future. The Labovitz study found that in 1967, although only relatively few foundations with assets of less than one million dollars ever held five per cent of the stock of a single business, more than half of those with assets over one million dollars held at least 25 per cent of the stock of a single business. ${ }^{59}$ The Council Report shows that by 1973, 13 per cent of the foundations responding still held 20 per cent or more of the stock of a single business, ${ }^{61}$ which suggests

53. INT. Rev. Code of 1954, § 4942(g)(2).

54. INt. Rev. Code of 1954, § $4942(\mathrm{i})$.

55. INT. Rev. CoDe of 1954, § 4944.

56. Although the foundation having excess business holdings will not lose its exemption for regular tax purposes, it will be subject to an initial tax of five per cent on the value of such holdings and an additional 200 per cent tax if they are not disposed of within a "correction period" (ordinarily ninety days after notice by the Commissioner).

57. A five-year period applies in the case of certain holdings acquired after May 26, 1969. INT. Rev, Code of 1954, $\$ 4943$ (c)(5).

58. See note 21 supra.

59. Labovitz 97.

60. Council Report III-19 \& example 9. 
that there has been some diversification of holdings in the interim. The Labovitz study shows that for many foundations these holdings may constitute over half of their total assets. ${ }^{\text {i1 }}$ Although the size of the foundations having such holdings is not shown, the Council Report shows the average value of such holdings to be over eighteen million dollars. ${ }^{62}$ Divestiture of holdings of such magnitude will obviously pose a major problem for many foundations, but, surprisingly, less than half of those foundations with the problem which responded to the Council questionnaire indicated that they had yet made any plans for meeting the requirements of the statute. ${ }^{63}$ One problem is that often the most logical person to acquire such excess holdings is the creator of the foundation, or some other disqualified person. Although the 1969 Act permits an "arm's length" sale of such holdings acquired before $1969,{ }^{6.4}$ the Council Report notes that there is a need for a procedure to obtain an advance ruling on whether a particular divestiture to a disqualified person will be considered arm's length by the Internal Revenue Service. ${ }^{65}$ The Council Report further notes that one problem confronted by many foundations is the possibility that the acquisition of stock by some disqualified person collaterally related to the foundation may be attributed to the foundation even though it has no knowledge of such acquisition, and the person actually acquiring such stock may not even know of the existence of the foundation. ${ }^{6 i}$ Congressman Patman introduced legislation in the last Congress to shorten the divestiture period to five years, ${ }^{67}$ but the Council Report suggests that this is entirely too short, and that in fact, the current five year divestiture period for foundations coming into existence after 1969 should be extended to at least ten years. ${ }^{68}$

Both reports also note that many foundations have been deterred from an early divestiture of their excess business holdings by reason of the fact that any gain (representing appreciation in value subsequent to December 31, 1969) on such divestiture will be subject to the four per cent tax now imposed on investment income. ${ }^{69}$ It would certainly seem appropriate to eliminate the tax on gains resulting from divestitures required by the law, if not on capital gains entirely. This problem, however, may have largely disappeared for most foundations during the years 1973 and 1974 when stock prices generally declined below their values on December 31, 1969.

\footnotetext{
61. Labovitz 97.

62. Council Report fig. 9.

63. Council Report III-19, III-20.

64. Tax Reform Act of 1969, Pub. L. No. 91-172, \$101(1)(2)(B), 83 Stat. 533.

65. Council. Report VI-13.

66. Id.

67. H.R. ReP. No. 5729, 93d Cong., lst Sess. (1973).

68. Couvcil RePORT V1-12, VI-14.

69. Labovitz 96. See also Council Report III-5, V1-8.
} 


\section{B. Adequacy of Other Restrictions}

It is submitted that the enactment of section 4943 was an over reaction to a supposed abuse by a few foundations. It is true that there is evidence in both the Labovitz and the Council reports that foundations having sizeable holdings in a single business have experienced a lower rate of return on their total investment assets than foundations not having such holdings. ${ }^{70}$ If such holdings are not sound foundation investments, there is adequate encouragement to dispose of them in the minimum rate of return provisions of section 4942 and speculative investment prohibitions of section 4944. It is said that a loophole once existed allowing a settlor to insure continued domination of a family business through the device of transferring control to a private foundation which was controlled by members of his family, thus having such stock escape estate tax at his death and also obtaining sizeable income tax advantage during his lifetime. ${ }^{i 1}$ It is suggested that everything else being equal, the best investment is the one controlled by the investor, and that more often than not, a business with which the settlor has long years of experience will be worth much more to the foundation than some business with which neither it nor he has any familiarity. The abuse argument usually overlooks the permanent economic benefit to charity which the settlor has put beyond his reach by transferring control of the business to a foundation, even though sometimes in the past the economic benefit did not flow to charity for many years to come. ${ }^{72}$ The minimum distribution requirements of section 4942 should now be adequate to assure such benefits in the future, without requiring disposition of the business. ${ }^{73}$ It is also sometimes said that a foundation controlled business has a competitive advantage over other business. Again, it seems that the antitrust laws and the minimum investment return requirement are adequate to take care of such problems. This is not to say that every foundation management should be saddled with the control of an operating business, and there would certainly be merit in a requirement that every foundation charter authorize its trustees to dispose of any of its assets when deemed in the best interest of the foundation to do so, regardless of the terms under which such assets were received, but to require disposition of a controlled business even though the minimum return requirements of section 4942 and the speculative investment prohibition of section 4944 are not violated-as is now required by section 4943 - seems not only unnecessary, but often not in the interest of the affected foundations.

70. Labovitz 96-98; $c f$. CouNcıl RePort figs. 9, 10.

71. See S. Rep. No. 552, 91 st Cong., lst Sess. 35,39 (1969).

72. Id. at 39 .

73. Id. 


\section{IV}

\section{Self-Dealing Prohibition}

The self-dealing prohibitions of section 4941 have apparently had less measurable impact on private foundations than some of the other provisions of the 1969 Act. $^{74}$ The observation is frequently made, however, that the prohibition on transactions between the foundation and related parties applies, without regard as to whether the foundation would be better off as a result of the transaction. ${ }^{75}$ While the difficulty the Service had in enforcing the law prior to 1969, when only transactions not conducted at "arm's length" were prohibited, ${ }^{76}$ is understandable, there are frequently occasions when a foundation's interest can best be served by dealing with a creator, donor, or some other related person. An instance is recalled when a foundation client desperately needed funds which its creator would have been willing to loan at four per cent, but because of the self-dealing prohibitions, the foundation had to turn to a local bank where the best it could do was six per cent. The arguments for such a flat prohibition are not convincing. The Council Report suggests that where a foundation is able to demonstrate in advance to the satisfaction of the Commissioner that a transaction, otherwise prohibited, is in the foundation's best interest, it should be able to get an advance ruling permitting it to go ahead with the transaction. ${ }^{77}$ While the Commissioner is ordinarily reluctant to rule on such questions of fact, there is no more reason why he could not rule in such a situation than where he is required to do so under other sections-such as section 4942(a)(2), upon showing of "good cause," and section $367(a)$, upon showing of the absence of a tax avoidance purpose.

\section{$\mathrm{V}$}

\section{Grant Restrictions}

The restrictions of section 4945 on grants to individuals and non-public charities have clearly reduced the amounts of such grants being made by foundations. ${ }^{78}$ The Council Report shows that whereas 39 per cent of the

74. The commission of an act of self-dealing will not result in loss of exemption for ordinary tax purposes, but in the imposition of a five per cent initial tax (on the amount involved) on the "disqualified person" engaged in such act of self-dealing with the foundation and a $21 / 2$ per cent initial tax on any "foundation manager" (as defined) who knowingly entered into such act: if not corrected within a "correction period" (ordinarily ninety days after notice by the Commissioner), the "disqualified person" may be subject to an additional 200 per cent tax and the "foundation manager" to an additional 50 per cent tax. INT. Rev. CoDe of 1954, $\$ 4941$.

75. Labovitz 64: Council Report III-I.

76. INT. Rev. CoDf of 1954, ch. 1, \$503, 68A Stat. 166-67 (1954), prior to amendment by the Tax Reform Act of 1969.

77. Council RePort VI-13.

78. The incurring of any "taxable expenditure" described in section 4945 will result in the imposition of a 10 per cent initial tax (on the amount involved) on the foundation and a $2 \frac{1 / 2}{2}$ per cent initial tax on any "foundation manager" (as defined) who knowingly agreed to such expenditure; if not corrected within a "correction period" (ordinarily ninety clays after notice by the 
foundations made such grants before 1969 under circumstances where a foundation would be required to exercise "expenditure responsibility" under the law today, only 20 per cent now make such grants. ${ }^{79}$ The Labovitz study found that the paperwork required to see that the funds are expended for the prescribed charitable purpose, to obtain complete financial reports from the grantee and to submit detailed reports of such grants to the IRS, is simply too burdensome for most foundations. ${ }^{80}$ It found on the other hand that some foundations welcomed the requirement since it made it much easier to turn down borderline requests. ${ }^{81}$ Labovitz found that " $[\mathrm{W}]$ hile there was some concern among foundation administrators about the impact of the restrictions on grants to individuals for travel, study, or similar purposes, few significant alterations in foundation grant programs appeared to have resulted by mid-1972." 82 On the other hand, the Council Report found that whereas 32 per cent of its responding foundations offered scholarship and similar grants prior to the $1969 \mathrm{Act}$, only 19 per cent did so in $1974 .^{83}$ Many organizations have found particularly objectionable the present refusal of the Service to grant permanent approval to any company foundation scholarship program which grants scholarships to more than 25 per cent of the eligible applicants. ${ }^{84}$ Well-endowed foundations cannot reconcile themselves to the requirement of section 4942 that they pay out all of their income to carry out their exempt purposes, with the refusal of the Service to permit them under section 4945 to award scholarships except to every fourth applicant; and there is almost certain to be some change in the Service's position on this matter in the course of time. The Council Report also suggests that the expenditure responsibility requirement be lifted in the case of grants in any one year of less than five thousand dollars to any one grantee. ${ }^{85}$

Commissioner) the foundation may be subject to an additional 100 per cent tax and the "foundation manager" to an additional 50 per cent tax. Proscribed is any expenditure:

(1) to carry on propaganda. or otherwise to attempt to influence legislation within the meaning of subsection (e),

(2) except as provided in subsection (f), to influence the outcome of any specific public election, or to carry on, directly or indirectly, any voter registration drive,

(3) as a grant to an individual for travel, study, or other similar purposes by such individual, unless such grant satisfied the requirements of subsection ( $\mathrm{g}$ ),

(4) as a grant to an organization (other than an organization described in paragraph (1),

(2), or (3) of section 509(a)), unless the private foundation exercises expenditure respon-

sibility with respect to such grant in accordance with subsection (h), or

(5) for any purpose other than one specified in section $170(c)(2)(B)$.

INT. Rev. CODE OF 1954, $\$ 4945$ (d).

79. Council RePort III-18, III-19, example 8.

80. Labovitz 82-84.

81. Labovitz $84-85$.

82. Labovitz 85 .

83. Council Report III-17, example 7.

84. Council RePort VI-15, VI-16.

85. Council Report VI-15. 


\section{VI \\ REPORTING}

The additional reporting requirements of the 1969 Act-both in terms of furnishing additional information to the Internal Revenue Service and in making available detailed financial information to the public-have caused some additional work and expense to the foundations, but they do not seem to be a cause for major complaint. ${ }^{86}$ It may be interesting to note, however, that only 27 per cent of the foundations responding to the Council questionnaire were ever asked to see their annual financial report after notice of its availability was published in accordance with the Act, and only five per cent had requests from as many as twenty people to see their reports in $1973 .{ }^{87}$

\section{VII}

\section{TAX ON INVESTMENT INCOME}

The one feature of the 1969 Act which has drawn the most complaint and the one on which there seems to be the greatest agreement as to need for a change is the four per cent tax on investment income. ${ }^{88}$ Although justified in part as a means of financing greater supervision of foundation activities by the Internal Revenue Service, the total take from the tax in fiscal year 1974 alone was $\$ 76,617,000$ - or nearly half again as much as the aggregate amount spent by the IRS in auditing and supervising foundations of $\$ 53,200,000$ in all seren fiscal years 1968 through $1974 .^{89}$ The Hartke Report states that the Senate Subcommittee on Foundations received a substantial amount of testimony "that the money raised by this tax is money denied, not to the private foundation, but to the charitable recipient of the foundation's money" and concludes that "[t]he level of the excise tax should be reduced from 4 to $2 \%$." 91 It anticipates that, because the tax is deductible for purposes of the minimum distribution requirements of section 4942 , the saving to the foundations will be passed on automatically to other charities. ${ }^{92}$ This will not necessarily be so, however, in the case of those foundations which distribute more than the minimum return, but, as previously indicated, they are in the minority. ${ }^{93}$ As indicated earlier, ${ }^{94}$ the suggestion has been made that capital gains should be excluded from the rate base, but the Hartke Report does not direct itself to this problem. The Council Report also suggests that renewed

86. COUNCIL RePORT III-10.

87. Council Report III-10, fig. 7.

88. Labovitz 77. See also Council Report III-3, VI-8, example 2; Hartke Report.

89. Hartke Report 18314.

90. Id.

91. Hartke Report 18315.

92. Id.

93. See text at notes $32,33, \& 37$ supra.

94. See text at note 69 supra. 
consideration be given to basing the fee on a percentage of investment assets, rather than on a percentage of investment income, noting that the present method tends to inhibit foundations from seeking to increase their investment return. ${ }^{95}$ The use of assets as a rate base was originally proposed in the Senate when it was considering the 1969 legislation, but the Treasury successfully persuaded the Conference Committee to adopt the income base instead of the asset base because of the greater simplicity of determining income than asset value. ${ }^{96}$ The Treasury's view has been borne out to some extent by the finding of the Council Report that over 20 per cent of the responding foundations have experienced valuation difficulties in applying the minimum investment return rules of section $4942 ;^{97}$ however, since experience now indicates that nearly every foundation must value its assets in any event to comply with section 4942, the Treasury's original objection to basing the section 4940 tax on value of assets now seems to have less validity than before.

\section{VIII}

\section{Gifts to Private Foundations}

There seems to be little doubt that the amount of giving to foundations has been considerably reduced as a result of the 1969 Act. The Labovitz study shows that the number of foundations receiving contributions from all sources declined roughly a quarter from 1967 to 1970 , and that the average contribution received in 1970 was roughly half of the average contribution in $1967 .{ }^{98}$ These figures are not conclusive, because economic conditions were not as good in 1970 as in 1967, but it is doubtful that the severity of the drop can be attributed entirely to economic factors. In 1973-a better economic year -only 36 per cent of the foundations responding to the Council's questionnaire received contributions from any source, ${ }^{99}$ as compared to 50 per cent in 1957 and 38 per cent in 1970 , according to the Labovitz study. ${ }^{10 \prime \prime}$

The drop has apparently been most severe in the case of inter vivos gifts. Whereas a Treasury study indicated that in 1962 foundations received more than twice as much support from inter vivos gifts than from bequests, ${ }^{111}$ the Council Report shows that in 1973 inter vivos gifts received by reporting foundations were less than half of bequests received. ${ }^{102}$ The Council Report suggests that the decline in inter vivos giving is attributable in part to the limitation on

95. Council Report Vi-8.

96. See the discussion in Hartke Report 18313.

97. Council Report III-14, example 5.

98. Labovitz 99.

99. Council Report II I-23c.

100. Labovitz 99 .

101. Treasury Department Report on Private Foundations, 89th Cong., 1st Sess. 71

(Comm. Print 1965).

102. Council Report III-23a. 
the amount that can be deducted under the 1969 Act for income tax purposes for gifts of appreciated property to private non-operating foundations; ${ }^{113}$ the 20 per cent limit on deductions for gifts of all kinds to private non-operating foundations, as compared to the 50 per cent limit for gifts to public charities; ${ }^{104}$ and the fact that other prohibitions on private foundation activity (such as the stock divestiture provision and the potential imposition of excise taxes on foundation management $)^{105}$ has generally made private foundations less attractive and a far more complex means of tax planning. ${ }^{106}$ The last of these, of course, applies to testamentary as well as inter vivos gifts. It is not entirely clear whether gifts which formerly would have been made to private foundations are now going directly to public charities. ${ }^{107}$ The Council Report indicates that total charitable giving in the United States increased from $\$ 12,220,000,000$ in 1965 to $\$ 24,530,000,000$ in 1973 and that in each instance approximately three-fourths of such gifts were inter vivos gifts of individuals. ${ }^{108}$ This is somewhat surprising in the light of the fact that some restrictions were imposed in the 1969 Act on all charitable giving, such as the limitation on deduction of property produced by the donor's own efforts ${ }^{109}$ and the requirement that gifts in trust be in the form of charitable remainder annuity trusts, charitable remainder unitrusts, or pooled income funds. ${ }^{11 "}$ Perhaps these restrictions were more than offset by the increased overall limitation from 30 to 50 per cent on gifts to public charities. ${ }^{111}$

\section{IX}

\section{Death and Birth Rates of Foundations}

There is strong evidence that many private foundations have simply elected to liquidate rather than go through the trials, tribulations and costs of compliance with the 1969 Act. Commissioner Alexander reported in a letter to the Senate Subcommittee on Foundations on October 2, 1974 that 4,892 non-operating private foundations had terminated their status since the effective date of the 1969 Act. $^{12}$ This represents approximately 15 per cent of all of the private non-operating foundations in existence when the 1969 Act was enacted. ${ }^{113}$ Professor John Simon of the Yale Law School has noted that,

103. INT. Rev. Code of 1954, § 170 (e)(1)(B)(ii).

104. INT. Rev. Code of 1954, $\$ \$ 170(\mathrm{~b})(1)(\mathrm{A})$, (B); see note 18 supra.

105. INT. ReV. Code of 1954, $\$$ 508, 509, 4940-48.

106. Council Report III-25.

107. Labovitz 102; Council Report III-23b.

108. Council Report table 14, quoting from F. Emerson Andrews, Philanthropy in the

United States: History and Structure 9 (1973).

109. Int. Rev. CoDe of 1954, § $170(\mathrm{e})(1)$.

110. INT. Rev. CoDe of 1954, $\$ 170(\mathrm{f})(2)$. Also see the restrictions in $i d . \$ \S 170(\mathrm{f})(3)$, (4).

111. Compare INT. Rev. Code of 1954, ch. $1, \S 170(\mathrm{~b}), 68 \mathrm{~A}$ Stat. 58, as amended 26 U.S.C.

$\S 170$ (b) (Supp. 1975) with INT. Rev. CoDE of 1954, \$170(b).

112. See Council Report III-22.

113. Council RePort 11-1. 
based on a count of new foundations recognized by the Internal Revenue Service in a given period in 1969 before enactment of the new Act, and a comparable period in 1973, less than half as many new private foundations were established in 1973 as in $1969 .{ }^{114} \mathrm{He}$ also noted that a similar count showed more than three times as many foundations being terminated in 1973 than in a comparable period of $1969 .{ }^{115}$ Perhaps even more disturbing is the Foundation Center's analysis of the establishment and dissolution of foundations in a twelve-state area; these figures show that in 1968 1,228 new foundations were established and only seventy-one dissolved, whereas in 1972, 128 were established and 605 dissolved. ${ }^{116}$ Hopefully, most of the organizations which are unable, or simply unwilling, to comply with the 1969 Act have now been dissolved, so that the number of dissolutions in the future will decline. Nevertheless, the decline must be very striking to avoid all alarm.

$\mathrm{X}$

\section{Internal Revenue Service Administration}

Prior to 1969, compliance by exempt organizations "had a relatively low order of priority" in the planning of the Internal Revenue Service. ${ }^{117}$ Audits of exempt organizations produced very little revenue-only five million dollars out of total tax revenues of almost two hundred billion dollars ${ }^{118}$-and there was reluctance to devote limited resources to such a poor measurable result. This attitude ignored the danger of widespread abuse of claims to tax-exempt status contrary to the public interest and the responsibility placed on the Internal Revenue Service as the only agency of the Federal Government empowered to prevent such abuse. Even prior to final enactment of the 1969 Act, Commissioner Randolph Thrower recognized the need for a more active program to insure compliance by organizations claiming tax exemption under the statute. He directed that exempt organization compliance activities be concentrated in fifteen "key districts" located throughout the country and staffed with agents specially trained in the exempt organization area. ${ }^{119}$ Shortly thereafter, an Exempt Organizations Branch was created in the National Office Audit Division under the supervison of the Assistant Commissioner (Compliance) for the sole purpose of directing and overseeing the audit of exempt organizations. The number of employees assigned to such

114. Hearings, supra note 8 , at 174-75, summarized in Council REPORT example 11.

115. Id.

116. Council Report III-23a, chart 2.

117. Address by Commissioner Thrower, Tax Executives' Institute in New York City, Sept. $21,1970$.

118. Address by Commissioner Thrower, American University Conference on Non-Profit Organizations in Washington, D.C., Feb. 18, 1971.

119. Address by Commissioner Thrower, California CPA Society 1969 Tax Accounting Conference in Los Angeles, Nov. 11, 1969. 
audit activities nationwide increased from 263 in 1968 to 344 in 1970 , and to 644 in 1972. In addition, the Exempt Organizations Branch in the National Office Tax Rulings Division under the supervision of the Assistant Commissioner (Technical) was increased from eighty employees in 1968 to 131 in 1971. ${ }^{20}$ Implementing this program was not without difficulty. As later explained by Commissioner Walters, IRS "agents usually are accountants, trained and oriented toward auditing complex books in search of items of revenue for the Government." ${ }^{21}$ It is difficult sometimes for them to "grasp the subtleties of the law of charities, trust law, and the deeper philosophical implications of the Government's duty to help the private sector promote the public good through a wide range of imaginative and innovative programs." 122 They need at times to be "lawyers, philosophers, scientists, theologians and, of course, these they are not."123

There was also established in 1969, prior to final enactment of the Tax Reform Act, a Commissioner's Advisory Committee on Exempt Organizations, headed by a former Under Secretary of the Treasury and composed of fifteen men and women from throughout the country prominent in a broad range of disciplines, such as philosophy, theology, education, the physical sciences, economics, business, law, and accounting. ${ }^{124}$ With this Committee the Commissioner, the Chief Counsel, and members of their staffs met regularly during the next several years to obtain guidance and suggestions with respect to numerous exempt organization problems-both substantive and procedural. During this period, the Service was faced with the especially difficult question of determining the meaning and outside perimeters of the word "charitable" as used in section 501(c)(3)-particularly in such areas as public interest law firms, racially segregated private schools, imposition of minimum charges by non-profit hospitals, and the financing of businesses for minority groups. Regulations under the 1939 Code provided that corporations organized and operated exclusively for charitable purposes comprise, in general, organizations for the relief of the poor. ${ }^{125}$ In 1959 the Regulations were broadened to provide that the term "charitable" in section 501 (c)(3) was to be construed "in its generally accepted legal sense" and included "[r]elief of the poor and distressed or of the underprivileged; advancement of religion; advancement of education or science . . . lessening of the burdens of Government; and promotion of social welfare by organizations designed to accom-

120. Address by Commissioner Thrower, supra note 118 .

121. Address by Commissioner Walters, Tax Exempt Organizations Institute in San Diego, July 12, 1973.

122. Id.

123. Id.

124. Address of Commissioner Thrower, supra note 119.

125. See, e.g., Treas. Reg. 111, § 29.101(6)-1 (1943). 
plish any of the above purposes ...."126 And in more recent years the Service, following the law of trusts, has recognized that the term is not a static, but a fluid one, as public needs and demands change.

Enactment of the 1969 Act necessitated intensified efforts on the part of the Service to deal not only with these problems, but with the many new concepts in that Act. Reference has already been made to some of the troublesome problems of interpretation in the issuance of new regulations called for by the Act. Especially difficult were the promulgation of regulations dealing with community trusts, scholarship funds, charitable remainder annuities and unitrusts, and, accordingly, much of the time of the Regulations Policy Committee-composed of the Commissioner, Assistant Secretary, Chief Counsel and Assistant Commissioner (Technical)-was spent in 1970, 1971, and 1972 struggling with these problems. The sheer volume of the new regulations required by the Act-aggregating several hundred pages-and the urgent demands of charitable organizations, particularly private foundations, to know as quickly as possible the position the Service would take in such regulations accentuated the problem. ${ }^{127}$

In 1969, the Service also undertook to carry out the recommendation of the Peterson Commission that every foundation be audited at least once in the next three years. ${ }^{128}$ Subsequently, a program was adopted to examine large foundations on a two-year cycle, and all others on a five-year cycle ending no later than December 31, $1974 .^{129}$

From 1969 to 1972, the Exempt Organizations Branch under the Assistant Commissioner (Technical) increased the number of advance rulings in exempt organization matters from 1,400 to more than 3,200 and the number of technical advice letters to the field in exempt organization matters from 240 to $610 .{ }^{130}$ The latter is particularly significant because all requests for technical advice are originated by audit personnel in the field, and these figures indicate that despite their greater sophistication in dealing with exempt organization matters, the number of audits they are undertaking require increasingly greater advice from the National Office.

The attitude of the Service in conducting private foundation audits is of particular significance. In 1970 a memorandum was distributed to Service personnel stating: ${ }^{131}$

126. Treas. Reg. $\$ 1.501(\mathrm{c})(3)-1(\mathrm{~d})(2)(1959)$

127. During the fiscal year 1971 , the Legislation and Regulations Division of the Office of the Chief Counsel, working with representatives of the Assistant Commissioner (Technical) and the Office of Tax Legislative Counsel, issued more entirely new regulations in proposed or final form than had been issued in the prior five years, or in any single earlier year.

128. Commission on Private foundations and Philanthropy, Report to the Senate Finance Committee (1969). Peter G. Peterson was chairman of the Commission.

129. Address by Commissioner Walters, supra note 121 ; Address by Commissioner Alexander, Council on Foundations in Dallas, May 10, 1974.

130. Address by Commissioner Walters, supra note 121.

131. Id. 
These private foundation provisions must be interpreted and administered in light of their special purpose and their individual structure as a group in the Code. Their purpose is not to raise revenue; they are designed to act as a guardian to insure that foundation assets will be put to charitable uses. In interpreting and administering these provisions, a strict adversary position should not automatically be taken. They call for an extraordinary degree of care and judgment in their application. We should not assume that private foundations are subject to a presumption of impropriety in their dealings or that it is the role of the Treasury Department to discourage their existence.

Sanctions should be imposed only where appropriate and every effort should be made to carry out the Congressional intent to benefit, rather than impede, charity. Each factual situation must be examined on its own merits and a threshold decision made whether it violates the basic intent and spirit of the provisions. If it does not, then the purportedly charitable activity should be allowed to continue, and we should not attempt to proscribe such activity by creating formalistic, unworkable, or unreasonable rules, through strained interpretations of the Code provisions.

The Employee Retirement Income Security Act of 1974 requires that the responsibilities of the Internal Revenue Service in the Exempt Organizations and Employee Plans areas be consolidated and coordinated by a new Assistant Commissioner for Employee Plans and Exempt Organizations. ${ }^{132}$ Technical and audit functions have been merged into this new office. The number of key districts has been increased from the original fifteen to nineteen, and the position of Assistant Regional Commissioner (Employee Plans and Exempt Organizations) was created in each of the seven Internal Revenue regions with the objective of giving greater emphasis and high level attention to Exempt Organization and Employee Plan matters and doing so in a more consistent manner. ${ }^{133}$

All of these activities insure greater attention by the Internal Revenue Service to private foundations, and the necessity that they give closer attention to the new requirements of the law and regulations. At the same time it seems likely that with the added expertise there will probably be a more fair, evenhanded treatment of the problems of foundations under the law.

\section{Conclusion}

What is the message of all this? Unless there is some change in the statute, it is quite evident that the private foundation movement has lost much of its vitality. Not only is the birthrate down, but the deathrate now far exceeds the birthrate; not only is the number of new gifts to existing foundations down, but the size of the gifts is also down; not only is the source of funding diminished, but the cost of compliance with the new law has increased, and unless foundations either find a better way to invest their money, or Congress

132. INT. Rev. Code of 1954, § 7802(b).

133. Address by Alvin D. Lurie, Assistant Commissioner (EPEO), Section of Taxation, American Bar Association, in San Diego, Feb. 7, 1975. 
reduces the minimum rate of return expected of their investments, they will be forced each year to deplete their capital-a capital which already, on account of inflation, is diminishing steadily in value.

The Council on Foundations concludes in its report that: ${ }^{134}$

[T] he 1969 Act has done much to rid the field of abuses and stir many of its members to a more conscious and more active sense of philanthropic obligation.

[M]ost foundations have managed to learn to live with the new law, and there is an informal consensus that it has, in fact, removed much of the potential for abuse and improved the responsiveness of the field to public needs and interests.

Nevertheless, it is clear that the 1969 Act has also restricted the ability of private foundations to assist in meeting the demands of society and unless amended in some of the areas mentioned above, it will continue to do so. Senator Hartke notes in his report that "[i]t is significant that the Subcommittee on Foundations has received only a handful of complaints suggesting abuses on the part of foundations," and then concludes: "In our pluralistic society, we should never depend on government alone to support research and innovation. Foundations offer an alternative to that dependence, and-as such-they should be welcomed and encouraged."135 There are many provisions in the 1969 Act which serve the public good, but it is to be hoped that Senator Hartke's admonition will be kept in mind by the Congress, and that instead of continuing to "cut off the dog's tail an inch at a time,"136 it will do all that can be done to restore the foundation movement to good health as a vital part of American society.

134. Council Report V-4, III-2.

135. Hartke Report 18314.

136. See text at note 3 supra. 